\title{
Working Together: Theories and Thoughts on Collaborative Capital
}

Citation for published version (APA):

van Emmerik, H. (2011). Working Together: Theories and Thoughts on Collaborative Capital. Oce Van der Grinten. https://doi.org/10.26481/spe.20110401he

Document status and date:

Published: 01/04/2011

DOI:

10.26481/spe.20110401he

Document Version:

Publisher's PDF, also known as Version of record

\section{Please check the document version of this publication:}

- A submitted manuscript is the version of the article upon submission and before peer-review. There can be important differences between the submitted version and the official published version of record.

People interested in the research are advised to contact the author for the final version of the publication, or visit the DOI to the publisher's website.

- The final author version and the galley proof are versions of the publication after peer review.

- The final published version features the final layout of the paper including the volume, issue and page numbers.

Link to publication

\footnotetext{
General rights rights.

- You may freely distribute the URL identifying the publication in the public portal. please follow below link for the End User Agreement:

www.umlib.nl/taverne-license

Take down policy

If you believe that this document breaches copyright please contact us at:

repository@maastrichtuniversity.nl

providing details and we will investigate your claim.
}

Copyright and moral rights for the publications made accessible in the public portal are retained by the authors and/or other copyright owners and it is a condition of accessing publications that users recognise and abide by the legal requirements associated with these

- Users may download and print one copy of any publication from the public portal for the purpose of private study or research.

- You may not further distribute the material or use it for any profit-making activity or commercial gain

If the publication is distributed under the terms of Article $25 \mathrm{fa}$ of the Dutch Copyright Act, indicated by the "Taverne" license above, 


\section{Maastricht University}

Prof. dr. IJ. Hetty van Emmerik

School of Business and Economics

\section{Working Together: Theories and Thoughts on Collaborative Capital}

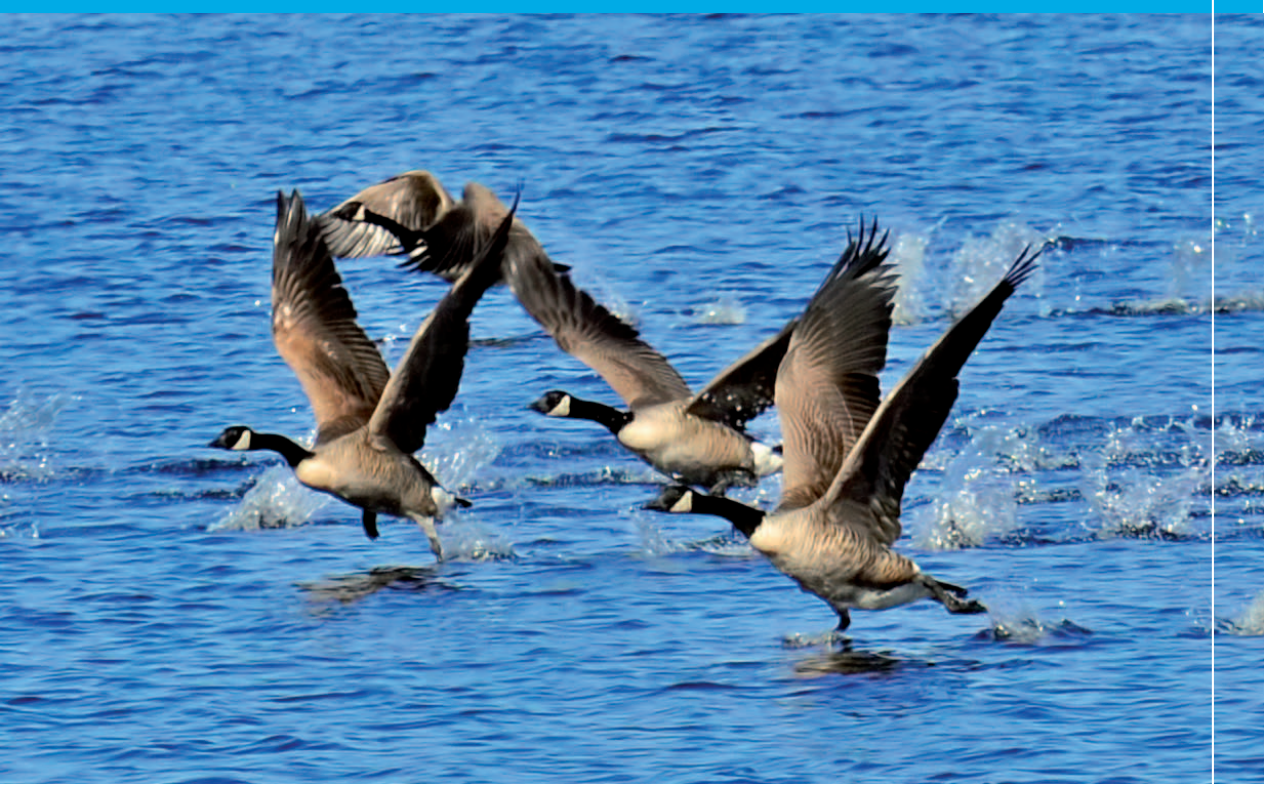




\section{Working Together: Theories and Thoughts on Collaborative Capital}




\section{Colofon}

Ontwerp en print: Océ Business Services, Maastricht

ISBN: 978-90-5681-368-0

NUR: 780

Alle rechten voorbehouden. Niets uit deze uitgave mag worden verveelvoudigd, opgeslagen in

een geautomatiseerd gegevensbestand of openbaar gemaakt worden, zonder voorafgaande

schriftelijke toestemming van de auteur of uitgever.
Working Together: Theories and Thoughts

on Collaborative Capital

Rede uitgesproken bij de aanvaarding van het ambt van Hoogleraar Organisatie Theorie en Organisatie Gedrag aan de School of Business and Economics van de Universiteit Maastricht

Maastricht, 1 april 2011

Prof. Dr. IJ. Hetty van Emmerik 
Mijnheer de Rector en Mijnheer de Decaan van de School of Business and Economics

Gewaardeerde collega's,

Lieve familie en vrienden,

Geachte toehoorders,

\section{Working together and sharing a common direction ${ }^{\mathrm{I}}$}

Many large birds, such as geese and pelicans, fly together in $\mathrm{V}$-formation. By flying in $\mathrm{V}$-formation, the birds flying in front create an updraft for the ones that are following. In this way, birds reduce power demands and spend less energy on their long flights. Pelicans flying in a V-formation can glide for extended periods using the other birds' air streams. Geese flying in a V-formation can travel up to 70 percent further than when flying alone. On long flights, the goose flying in front of the formation will eventually drop back to take a lower place in the $\mathrm{V}$ where the flying is easier. Then, another goose will take over the front position. Flying in V-formation also enables geese to monitor each other and provide help when necessary. If one goose drops out of the formation completely, for being sick or whatever reason, at least two of the other geese also drop out to help and to protect the ailing one. Geese communicate when they fly and, as far as we know, geese can make at least ten different calls. They alert each other regularly and they "honk" to indicate that it is time for a rest. They "honk" to their companions about likely landing locations and they "honk" to warn each other of potential danger (Muna \& Mansour, 2005). One could say that flying together in a common direction is what makes geese and pelicans arrive at destinations out of reach for any bird travelling on its own. ${ }^{\text {I }}$

Geese and pelicans, as these examples show, excel in working together in teams. Teamwork, which is what this lecture is about, refers to exactly this: working together and sharing a common direction. By working together, team members can achieve goals in ways more efficient and effective than by working alone. By working together, teams can create and tap resources that are non-accessible to individuals working in isolation. In this lecture, I will focus on how team members working together tap these resources and create, what is called, collaborative capital. Much research has already been done on the factors that are important for building collaborative capital. I will draw on some of the topics from my own research in this area and elaborate on these examples. At the end of this lecture, I will focus on future research avenues and how research in this field can help theory development and inspire teamwork in organizations. 


\section{Working together in teams}

A team is as "a distinguishable set of two or more people who interact dynamically, interdependently, and adaptively toward a common and valued goal, object, or mission, who have each been assigned specific roles or functions to perform" (Salas, Dickinson, Converse, \& Tannenbaum, 1992, p. 126-127).

Formal work teams are groups of individuals who share responsibility for specific outcomes in organizations. Within organizations, we can see numerous types of formal work teams: task groups, project teams, committees, quality circles, and top managements teams (Raes, Heijltjes, Glunk, \& Roe). As teams are becoming the basic building block of organizations, the effective functioning of organizations is nowadays heavily dependent upon the capabilities of teams (Mathieu, Maynard, Rapp, \& Gilson, 2008). In the Netherlands, around $70 \%$ of organizations use formal work teams, making the Netherlands one of the countries in the European Community where teamwork is relatively common. On average, around $58 \%$ of organizations in the European Community rely on teamwork (European Foundation for the Improvement of Living and Working Conditions, 2007).

As is the case with geese and pelicans, teamwork in organizations also makes it possible to achieve goals more efficiently and more effectively than when working alone. By working together team members create so-called collaborative capital (Beyerlein, Beyerlein, \& Kennedy, 2005) referred to as (group) social or relational capital (Leana \& Van Buren, 1999; Oh, Chung, \& Labianca, 2004; Van Emmerik \& Brenninkmeijer, 2009). Collaborative capital is the configuration of the social relationships within the team through which necessary resources for the group not only can be accessed but also can be created. Collaborative capital is different from individual-level social capital because it is shared between the team members. It is also a way of examining in greater depth how social relationships within teams are related to group outcomes, such as knowledge sharing behaviors. Collaborative capital refers to the creation of resources embedded within, available through, and derived from the relationships of team members. Importantly, collaborative capital leads to more team learning (behaviors through which team members seek to acquire, share, refine, or combine task-relevant knowledge of teams; Van Der Vegt and Bunderson, 2005) which, in turn, positively relates to team outcomes.

Often, humans working in teams do not match geese and pelicans in their capacity for teamwork, but we can observe similarities. Some of these similarities include (Muna \& Mansour, 2005; Whetten \& Cameron, 2008):

- In effective teams, members will be more effective working together than when working alone. Like geese, effective teams most frequently outperform even the best performing individual.

- Team members depend on each other when performing tasks. Like geese, the productivity and efficiency of an entire unit is determined by the combined efforts of all its members.

- Like geese, team members desire to belong to a (specific) team and they value the advantages of belonging to a team.

- Like geese, in effective teams, members can trust each other and team members care for and support each other.

\section{Theories and Research on Collaborative Capital}

In the following part of this lecture, I will elaborate on different features of working together and the creation of collaborative capital from an Organizational Behavior point of view. ${ }^{1}$

At first sight, one may think that Organizational Behavior is about the behavior of organizations. This, however, is not in line with the allembracing definition of Organizational Behavior. Instead, Organizational behavior focuses on the human behavior within organizations. For example, if we were to study the organizational behavior of Maastricht University, we would include the characteristics of individual employees, the formal relationships between individuals, and how individuals within Maastricht University relate to each other in work teams and in informal gatherings. We would study how individuals think and feel about their work, how committed they are to Maastricht University, and how engaged they are in their work. In addition the values, goals, and

In the field of Organizational Behavior, the word capital is used frequently (e.g. human capital, psychological capital, and social capital). Capital refers to all kinds of resources found, created, and sustained within organizations. The creation of resources among team members has been described in the organizational literature with the nebulous term social capital and more recently somewhat more specific as collaborative capital (Smith, 2005). The term collaborative capital will be used throughout this lecture because it is more specifically focusing on the creation of resources by team members working together 
policies, such as Human Resource Management, of the faculties and of Maastricht University as such would be a subject of study. A complete study would be an enormous undertaking, complicated by the fact that each of these elements are interdependent and mutually affect each other (see Daft \& Noe, 2001). So, most frequently, we highlight some of these elements, but this example nicely illustrates the breadth and depth of the field.

As one may expect from this overview, team work is one of the most prominent topics in Organizational Behavior. As team work becomes increasingly important, it is critical to examine how to promote the creation of collaborative capital in teams. Therefore, in the next part of this lecture, I will elaborate on collaborative capital residing within teams and the research that I have done with respect to the opportunities to create collaborative capital. I will end this lecture with some topics that are high on the research agenda of the field of collaborative capital.

\section{Structural properties}

I start with elaborating on the structural properties of teams. We know from research that some structural properties of teams can lead to more collaborative capital. For instance, hierarchical position determines in part the opportunities to create collaborative capital (Van Emmerik, 2006). And certainly other structural properties will also be important. For now, I will concentrate on two aspects, that is, the size of the team and the composition of the team.

Size. One of the first characteristics of teams that are important in understanding the process of creating collaborative capital is the size of the team.

Team size is expressed in the number of people working on a team. The more people on a team, the more opportunities may exist to collaborate and to create collaborative capital. While intuitive, it is not always the case that larger teams perform better or create more collaborative capital. One problem is that individuals working on large teams may not know who is responsible for executing certain tasks. Another problem is that the more individuals on a team, the less efforts team members may put into joint tasks, a phenomenon known as social loafing. Finally, large groups offer fewer opportunities to assess the efforts each individual puts forth to the collective task. As a result, some individuals may shirk.
While the size of a team is essential to the creation of collaborative capital and the attainment of team goals, it is not trivial to determine the optimal team size. Optimal team size depends on many things, such as, the task at hand, the required amount of coordination, and the level of education of the members. Still, one rule of thumb is that teams should have between six and ten members (De Janasz, Dowd, \& Schneider, 2006). Normally, this is large enough to accomplish the work and provide enough resources and ideas, and small enough for team members to care, to support each other (Van Emmerik \& Peeters, 2009), and to grow together in order to create collaborative capital. Again, it appears that work teams cannot match the team work capacities of their counterparts in the wilderness; geese are known to form flocks that may vary between twenty and more than three thousand geese (Amano, Ushiyama, Fujita, \& Higuchi, 2006)

Composition of the Team: Demographic Diversity and Deep Diversity. More complex than size, is the composition of the team. Within teams quite different and diverse employees can be brought together. Team members may incorporate a variety of ideas and ways of working, and may represent different backgrounds and expertise. Indeed, working in a team most frequently requires a variety of competences, skills, and knowledge. Given this need for different expertise, it seems reasonable to propose that heterogeneous teams will do better in building collaborative capital.

Consider a team of doctors. ${ }^{2}$ Let's assume that members of this medical team are about the same age, all trained in medicine, and all male. They form a team that is highly similar in demographics or to put it the other way around, they score low on heterogeneity. One of the best examples of how such demographic similarity may affect team functioning and the creation of collaborative capital is the ratio of men and women in a team. In her seminal work on gender ratios, Kanter (1977) argued that particularly the proportion of women in predominantly male groups (tokens) leads to different dynamics in teams. She advocated a stronger numerical representation of women in management. Ever since, the proportion of women in managerial positions has attracted attention as one of the structural properties that may affect leadership behavior, as well as opportunities to create collaborative capital.

2 This example is adapted from Harrison, D. A., \& Klein, K. J. (2007). What's the difference? Diversity constructs as separation, variety, or disparity in organizations. Academy of Management Review, $32(4), 1199-1228$ 
Although originating in the seventies, the ideas of Kanter are still present today. A recent study, building on her ideas, showed that if one wants to change leadership styles in a company, it is good to know that men are sensitive to the gender ratio and act accordingly by changing their leadership style (Van Emmerik, Wendt, \& Euwema, 2010).

Deep Similarity. Next to demographic similarity, we also recognize another type of diversity called deep similarity or conversely deep diversity. Think again of the team of doctors. Consider doctors who differ in their ideas about how to cure patients. Some of the medical experts may favor clinical trials adhering to the tradition of conventional medicine. Some other doctors on the team may hitch onto herbal medicine and belief that patients might be harmed by using poisoning substances like conventional medicine. Still others in the team may favor acupuncture to cure medicine and don't want to use any medicine or herbs.

This type of difference, evident in different paradigms of how to cure patients, is referred to as deep (or deep-level) diversity. This type of diversity concerns the rather invisible differences in values, attitudes, preferences, and beliefs of team members. To measure deep similarity scholars would ask people how much they identify with team members who are similar to themselves with respect to different characteristics (Van Emmerik \& Euwema, 2008). Characteristics, for example, would include; sharing the same vision, having the same passion for the job, feeling the same love for being a teacher, working in the same way, and sharing the same goals.

If measured in this way, it was found that deep level similarity was more important than demographic similarity for creating collaborative capital. Importantly, teams may benefit mostly from deep-level similarity when working in an environment where employees do share and do exchange common experiences, knowledge, and values (Van Emmerik \& Brenninkmeijer, 2009).

\section{Relational Properties Important to Explain the Creation of Collaborative}

\section{Capital}

Next to the size and the composition of the team, processes and relationships within teams are important aspects that help explain the creation of collaborative capital.
Communication. The first relational property is communication within the team. Communication is important for creating and sustaining collaborative capital because it provides team members with various benefits, such as information, influence, and control. Team members can improve their team's collaborative capital if they interact and share their expertise and use their collaborative capital.

In the literature, we come across the term shared mental models (Nahapiet \& Ghoshal, 1998). This term describes one of the most important underlying mechanisms of effective teamwork. Shared mental models are knowledge structures team members rely on to organize new information, to describe and explain the work to be done, as well as to guide their interaction with other team members. A shared mental model reflects the team objectives, team mechanisms, individual roles, individual responsibilities, and relationships among employees (see Mathieu, Heffner, Goodwin, Salas, \& Cannon Bowers, 2000). As such, the constructs collaborative capital and shared mental models have much in common.

Social networks. Another aspect of relationships within teams important to the creation of collaborative capital is the social network. With this, I don't mean Facebook, Hyves, or Linkedin. Instead, I use the term social networks to refer to the social relationships of people at work. Social networks are important to collaborative capital because the development of collaborative capital takes place in the work-related social networks of team members. In such social networks, team members share resources such as information, assistance, and guidance conducive to the creation of collaborative capital.

One good way to illustrate how the creation of collaborative capital depends on social networks is by looking at gender differences. Greater success of men in the creation of collaborative capital has been attributed to their more effective use of informal networks. In this context, networks are often referred to as old-boys networks. In such men-only networks, the creation of collaborative capital is facilitated by the homogeneous composition of the network. That is, in the old-boys network members are about the same in age, hold similar positions, and of course are of the same gender. Maybe then, as some have suggested, women need women-only networks to access resources that otherwise remain hidden. Research shows that women do engage in networking. In fact they do engage in all sorts of networks, e.g., networks of young employees or diversity network. However, women seem to 
target primarily formal networks. Further, women seem to gain less collaborative capital from their networking activities than men (see Van Emmerik, Euwema, Geschiere, \& Schouten, 2006).

However, it may not only be the homogeneity or heterogeneity of the networks that makes it more difficult for certain people to create collaborative capital, but also differences in the contents of the collaborative capital. A distinction can be made between two broad categories of collaborative capital (Van Emmerik, 2006):

- Hard collaborative capital refers to the creation of task-oriented resources that can be used to achieve valued career outcomes. Hard collaborative capital develops from the exchange of job-related resources. For instance, the creation of hard collaborative capital can be recognized in getting an important and prestigious assignment or funding/sponsorship.

- Soft collaborative capital refers to resources that can be used to get socio-emotional support. It refers to relationships that involve the exchange of friendship and social support. Soft collaborative capital is characterized by high levels of closeness and trust. Soft collaborative capital, such as counseling, friendship, and modeling, helps team members to develop self-esteem and professional identity.

Research shows that indeed both men and women can use resources in the work context to create hard and soft collaborative capital. Men are better able to create hard collaborative capital than women. Conversely, one may expect women to outperform men in the creation of soft collaborative capital. This, however, finds no support in research: Women do not appear to be better in the creation of soft collaborative capital. Hence, they are not the emotional specialists old stereotypes would make us believe (Van Emmerik, 2006). Well, six of one, or half a dozen of the other, much research can be done in this area.

Cohesion. In addition to communication and networking, there is also a more structural property that helps explain how social relationships can facilitate the creation of collaborative capital, that is, cohesion. Team cohesion seems to open opportunities for creating collaborative capital. Team cohesion is the degree to which team members feel attracted to a team, want to remain part of the team, and want to interact with one another in pursuit of common goals (Harrison, Price, \& Bell, 1998). Cohesion facilitates the creation of collaborative capital. Yet, cohesion may also have a downside. It appears that too much cohesion prompts for a more restricted normative environment which may have detrimental effects on cooperation (see Gargiulo \& Benassi, 2000).

\section{Explaining the Creation of Collaborative Capital by Contextual} Conditions

One may think of communication, networking, and cohesion as rather straightforward means to create collaborative capital. More indirect ways to create collaborative capital are anchored in the work environment and range from leadership and support from the environment to team climate.

Leadership. Leadership is one of the most prominent contextual factors that affect the creation of collaborative capital. Leaders can help teams to create collaborative capital by promoting team learning, by helping teams solve problems, by supporting the social climate, and by providing resources to the team (Morgeson, DeRue, \& Karam, 2010). To the extent that leaders encourage collaboration, facilitate open communication, and provide a trustful and enabling work environment, collaborative capital can grow.

Human Resource Management. A second contextual factor important for collaborative capital is the management of human resources. Human Resource Management fosters social networking and helps building collaborative capital. For instance, Human Resource Management practices may facilitate the development of advice relationships between team members (Van Emmerik, Schreurs, De Cuyper, \& Jawahar, 2011).

Team Climate. Less tangible than leadership and human resource management is team climate. Team climate refers to the perceptions of the work environment team members share. Such team context factors may exert strong influences on individual attitudes and behaviors, as social information processing theory would suggest (Salancik \& Pfeffer, 1978). In line with this research, team climate can act as a powerful facilitator for the creation of collaborative capital. A so-called supportive team climate reduces the risk that team members suffer from burnout and increases the chance that team members are engaged in their job (Van Emmerik, 2006). 
Since individuals interact more with their team colleagues than with members of other groups, teams will create shared meaning and interpret team events, practices, and procedures in similar ways. This process is called team sensemaking (see Roberson, 2006). While other processes also may explain how the environment or context influences team member behavior (see Schneider \& Reichers, 1983; Van Emmerik, 1991), here, I focus on processes of sensemaking in teams.

One factor that may explain why team members interpret work events similarly may be work values. Work values are the evaluative standards that define desirable ends and ways to achieve them. Teams can develop more intrinsic or more extrinsic work value orientations. Team members in intrinsically oriented work teams value personal growth and social bonding. Team members of extrinsically oriented work teams generally share the belief that success entails the continuous pursuit of prestige, status, and high income. People may feel attracted to teams that espouse values congruent to their own values. Thus, some people will be attracted to teams with an intrinsic orientation, whereas others will be attracted to teams with an extrinsic orientation. When team members experience misfit, less collaborative capital will be created. Consequently, members who do not support the team values may decide to leave the team and join another team with more compatible work values (see Van Emmerik, Schreurs, Guenter, \& Broeck, 2011).

Crossover and Norms. Compared to processes of sensemaking, crossover effects are more tangible. Crossover effects are quite specific and bear resemblance with contagious illnesses: When the greater part of team members has a cold this may increase the chances of the focal team member catching a cold but not to catch another disease (Van Emmerik \& Peeters, 2009). Scholars have used crossover models to explain how, amongst others, values, experiences, feelings, and emotions spread across individuals within a team (Bakker, Van Emmerik, \& Euwema, 2006; Bakker, Westman, \& Van Emmerik, 2009). For instance, in a study with more than 2,000 Royal Dutch constabulary officers (Dutch: Marechaussee) the likelihood of burnout was higher for those officers working in a team with a high percentage of burned out officers (Bakker et al., 2006). Another way to look at crossover is by looking at the transfer of norms.
Norms form one aspect of team climate. Norms are informal rules of how to behave. Norms help control the behavior of team members because norms specify the behaviors members should engage in and should not engage in. Teams typically provide their members with explicit expectations and rules on how to get the work done and how hard to work. Such norms affect the performance outcomes of individuals and of the team as a whole.

People in a team implicitly or explicitly communicate to each other what is acceptable behavior, and monitor each other's behavior to make sure everyone is conforming to the ideas of the team. This is key to controlling the group. Teams enforce norms by rewarding those team members that conform to the norm and discipline team members that break the rules. Consider for example a restaurant (George \& Jones, 2008). Waiters and waitresses may develop norms on what is appropriate and inappropriate behavior; while it is appropriate to inform colleagues of customers waiting for their check, it would be inappropriate to take each other's tables. It is easy to see that such norms help the group to function effectively and to earn the best tips possible. A waiter or waitress who goes against the norm by stealing tables to earn more tips might be brought to the attention of the restaurant manager and may eventually be fired. Waiters and waitresses who conform to the norms are rewarded with support from their colleagues. When norms exist, team members do not have to waste time thinking about what to do in specific situations. The prevailing norms guide members' actions and specify how to behave.

Another intriguing example of how norms may control behavior can be found in the literature on emotional labor which describes how people act out emotions. Emotional labor is performed through either surface or deep acting (Hochschild, 1979).

- Surface acting involves presenting emotions without actually feeling them. We all know examples of this, such as, the flight attendant who keeps smiling, the Disney crew member who keeps entertaining, and the call center agent who remains friendly over the phone, no matter what happens.

- Deep acting or authenticity applies when one experiences the emotions that one shows. Consider for example the doctor expressing genuine empathy for a patient when giving a terminal diagnosis. 
Teams develop norms about how to appropriately regulate emotions in different situations. Sometimes surface acting is more appropriate. For instance, we all like service with a smile. In more serious times deep acting or authenticity is more the thing that is prescribed. What is important is that within teams, working together is best facilitated when all team members' emotion regulation matches the team norms. Want to keep yourself happy and productive at work? Then better conform to the norm, a recent study suggests. Moreover, in teams where the emotion regulation of the focal employee is not congruent with the group norm, this may have adverse outcomes, such as impaired collaborative capital and ultimately reduced team performance (Van Emmerik, Bakker et al., 2010).

\section{Conclusion}

To wrap it up, in this lecture, I have concentrated on collaborative capital, that is, the value created by leveraging knowledge that is embedded in how people are working together in teams. I have explored three types of features important for the creation of collaborative capital, namely structural, relational, and contextual characteristics. These features may facilitate or hinder the creation of collaborative capital. These can be seen as antecedents, moderators, or mediators for collaborative capital.

Certainly, there are more factors and processes that may facilitate or hinder the creation of collaborative capital. To list some of them: providing feedback, fostering constructive conflicts, preventing destructive conflicts, etc. The list is long and much can be said about additional factors and processes. However, the purpose of this lecture was to give an overview of three important research streams on collaborative capital.

In describing what features are important for the creation of collaborative capital, I haven't paid much attention to why it is important to improve the creation of collaborative capital, although I can easily think of a laundry list' of variables that are correlated with collaborative capital. The essence, however, is that more collaborative capital makes more effective teams. That is because such teams have greater access to important resources necessary to maintain and improve their performance (see Oh et al., 2004).

\section{Exploring Avenues to Additional Research in Collaborative Capital}

Now that I have reviewed some critical topics in collaborative capital research, I want to look ahead to explore some avenues for future research. My focus is on three topics:

- Technological and methodological innovations;

- Using Human Resource Management to improve the effectiveness of diverse teams, and;

- Shifting from an individual to a team approach.

\section{Towards Dynamic Models of Working Together in Teams}

Theory building on team work is predominantly static and descriptive. Almost every textbook on teams refers to the model of team development of Tuckman (1965). This stage model of Tuckman describes a linear series of stages to capture team development. The model starts with a forming stage, where team members start working together and begin to function as a team. The next stage of storming is characterized by differences between the team members that may easily escalate into conflict. With time, however, storms will pass, and the next stage heralds the development of norms and rules about how to behave are established. Finally, the performing stage, with an emphasis on working together evolves.

Stage models, while applicable to a wide range of teams, are descriptive in nature. With the progress in multilevel and growth modeling, scholars have now the possibility to study how multilevel processes are dynamic, cyclical, and how they may unfold over time. One promising way to assess the dynamic development of teams is to advance the literature on spiraling effects (see for instance Günter et al., 2011). Another promising path is to build and test more complex growth models to study how teams develop collaborative capital over time and across levels.

Improving the Effectiveness of Diverse Teams

We saw earlier in this lecture that collaborative capital grows more strongly in homogenous teams than in diverse teams. However, in an increasingly globalized world, diverse teams will own the future. Hence, an important avenue for research is to understand and to illuminate how and when teams composed of people with different backgrounds, attitudes, beliefs, and cultures can optimally create collaborative capital 
(Kats, Van Emmerik, Blenkinsopp, \& Khapova, 2010; Van Emmerik, Gardner, Wendt, \& Fischer, 2010; Van Emmerik, Euwema, \& Wendt, 2008; Wendt, Euwema, \& van Emmerik, 2009). It will be quite a challenge to figure out under which conditions: 3

- Diverse groups can create more collaborative capital (in order to perform better) than homogeneous groups;

- Diverse groups can create more collaborative capital (in order to perform better) than even their best individual members.

To master this challenge, not only research is important. From a Human Resource Management perspective, we will have to develop diversity training programs, change reward structures in favor of teamwork, and stimulate intercultural competencies. With intercultural competencies I mean the abilities to think and act in intercultural appropriate ways. Intercultural competencies are necessary to improve team capabilities to create collaborative capital.

\section{Towards Focusing on Teams and Team Interventions}

Finally, for years, research on organizational behavior has focused on the individual team member. Although informative, such research does not account for the direct environment, be it the team or the organization, in which team members work.

For example. the often used Job Demands Resource Model (Demerouti, Bakker, Nachreiner, \& Schaufeli, 2001) argues that individuals are conducive to the effects of job demands and resources. In other words, the model focuses on how exposure to stress influences individual outcomes (see for instance Brenninkmeijer, Demerouti, Le Blanc, \& Van Emmerik, 2010; Demerouti et al., 2001). The consequence of using such individual outcome models is that interventions also will be implemented at an individual level.

Such individual interventions may overlook how team processes are important to individual behavior. Theories trying to explain the generation of collaborative capital, however, all emphasize the importance of teamlevel phenomena for individual experiences at work and work outcomes (e.g., Bliese \& Britt, 2001; Bliese \& Jex, 2002; Devine, Clayton, Philips, Dunford, \& Melner, 1999; Gully, Incalcaterra, Joshi, \& Beaubien, 2002).
Thus, to the extent that team work gains in importance, team monitoring and team interventions will need to move to the forefront of organizational research and practice (Van Emmerik, Euwema, \& Bakker, 2007)

To ensure that the team performs up to its potential and optimally uses collaborative capital, teams need to be monitored. This will include evaluating the team's progress, the availability of resources, and the ultimate performance of the team (Morgeson et al., 2010). To that end, firms regularly use employee surveys and monitors. Many organizations devote substantial effort to monitor the performance and well-being of individual employees. Results of such individual-level monitoring can be used for individual diagnostics but also for team diagnostics and interventions (Van Emmerik, Guenter et al., 2011; Van Emmerik \& Van vuuren, 2011).

Future research, it stands to hope, will generate further insights into how to develop and use collaborative capital in optimal ways. Similarly, future research needs to provide more systematic insights into interventions which can be implemented to achieve team effectiveness.

I started this lecture with the flying geese example. By flying in $V$-formation, these birds use structural properties of the team to increase efficiency of their team work. On their long flights, geese will use relational and contextual features, like communication, helping, and taking care of each other, to improve their effectiveness of flying in a team. In this way geese share a common direction. By flying together they are more efficient and more effective in achieving their goals than by flying alone. I hope I have been able to show that the formal work teams that I have been talking about share many similarities with the teams of geese.

3 A start is already made to examine these three conditions in Larson, J.R. (2007). Deep diversity and strong synergy: Modeling the impact of variability in members' problem-solving strategies on group problem-solving performance. Small Group Research, 38, 413-436. 


\section{Conclusie en Dankwoord}

Gekomen aan het het eind van mijn les, wil ik graag weer in het Nederlands verder gaan en een opmerking en dankwoord uitspreken.

\section{Probleem-Gestuurd Onderwijs}

In deze openbare les is het vooral gegaan over onderzoek, daarbij voorbijgaand aan het feit dat onderwijs ook een essentieel onderdeel is van het takenpakket aan de universiteit.

Voor wat betreft het onderwijs, is het credo van de Universiteit Maastricht Leading in Learning. Onderwijs dat vraagt om een heldere aanpak. Waarbij het vooral ook gaat om eigen verantwoordelijkheid van studenten. Het onderwijs dat we hier in Maastricht aanbieden is probleem-gestudeerd onderwijs dat wil zeggen dat studenten in kleine groepen onderwijs krijgen waar bij ze leren zelf verantwoordelijk te zijn. Daarnaast wordt vooral ook nadruk gelegd op het samen leren en hoe leeruitkomsten bevorderd kunnen worden in een klein team van studenten. Het onderwijs vindt dan ook grotendeels plaats in kleine groepen en maakt vooral geen gebruik van grote en massale hoorcolleges.

Het drie kwartier voorlezen van een rede, zoals de academische traditie vraagt, staat natuurlijk haaks op deze onderwijsfilosofie. Ook al betreft het zeker een mooi ritueel, erg effectief is het niet. Integendeel, vorige week hebben mijn studenten via presentaties nog weer eens heel overtuigend laten zien dat informatieoverdracht via pecha kucha's heel efficiënt is. In zes minuten tijd wordt informatie gecomprimeerd tot een multimedia informatiebom die eigenlijk veel beter past in deze tijd. Zeer waarschijnlijk had de inhoud van deze oratie prima gepast in dit format. Deze openbare les voorlezen is dus vooral een voorbeeld geweest van hoe het hoort in de academische traditie en hoe we het niet doen in het onderwijs.

\section{Dankwoord}

De Rector Magnificus Gerard Mols, de leden van het College van Bestuur, onze decaan van de School of Business and Economics Jos Lemmink, en alle overigen die aan mijn benoeming hebben meegewerkt, wil ik bedanken voor het vertrouwen mij gegeven.

Ik ben heel blij dat mijn promotor Pieter Cornelis hier aanwezig is - altijd inspirerend, altijd motiverend, was het een genoegen om samen met hem op één kamer de sectie bedrijfspsychologie zoveel mogelijk te laten groeien en bloeien.

Inmiddels ben ik al weer anderhalf jaar hier werkzaam binnen het departement Organisatie en Strategie, en het is een exciting challenge!

Graag wil ik Martin bedanken, ondanks zijn grondige hekel aan overleg en vergaderingen, is hij degene met wie ik overduidelijk het allermeest overleg over van alles en nog wat heb gevoerd. Daarnaast wil ik een aantal van mijn collega's noemen voor de mooie samenwerking aan allerlei projecten. Anita voor de mooie kans om te werken in een project over vrouwen en authentiek leiderschap. John voor het inzicht geven over het leven in de faculteit. Wil voor het uitbouwen van samenwerking buiten de universiteit. Andries voor de veelbelovende samenwerking op het gebied van monitoring, Wim en Mien voor het fascinerend project rond augmented reality. Ik ben ook veel dank verschuldigd aan alle mensen waar ik de laatste jaren mee heb gepubliceerd, eigenlijk te veel om op te noemen. Maar om toch een aantal zeer gewaardeerde co-auteurs te noemen: mijn oud-collega's uit Utrecht Arnold (nu in Rotterdam). Eva, Jos, Maria, Pascale, Rendel en Veerle. De hechte samenwerking met Martin E. en Hein (heerlijk al die prijzen!), Hans en Nele uit Leuven, en de vele, vele mensen die ik via de Academy of Management en de Southern Management Association heb leren kennen en waarmee ik heb mogen samen werken.

Een grote bron van inspiratie is de Organisatie groep waar ik Hoogleraar ben. Dit team heeft veel weg van de teams die ik hier voor besproken heb en we zijn hard bezig met het opbouwen van veel collaborative capital. Ik wil Ad, Bas, Bert, Boris, Desiree, Guy, Hannes, Jia, Maarten, Peter, Sara, Tom, en Ursula bedanken voor het enthousiasme, de steun en natuurlijk de uitdagingen die we elkaar bieden. Ik hoop dat we onze samenwerking nog lang kunnen voortzetten. Bert en Hannes wil ik speciaal bedanken 
voor alle inspirerende projecten zowel op het gebied van onderwijs en van onderzoek (in steeds moelijker multilevel teamprojecten), voor het becommentariëren van deze les, en ook voor het immer aanbieden van nieuwe ideeën -- van het schrijven van minstens een paper per maand maar soms ook per week, en bijvoorbeeld voor de kritische inspiratie geboden door de 'schaal van de week'.

Dan kom ik bij degenen die mij het meest na staan. Mijn kinderen, Lennart en Merel en mijn familie en persoonlijke vrienden. Lennart wil ik bedanken voor het immer bijdragen aan mijn zelfvertrouwen met de nooit aan kracht afdoende uitspraak "Hetje dat kan je zelf". Merel wil ik bedanken voor het immer bijdragen aan mijn organisatievermogen door de haar kenmerkende, ook niet aan kracht afdoende zorgzame uitspraak "Hetty, heb je al ..." en dan komt de hele rij van wat ik allemaal nog moet doen.

En dan kom ik bij Joost, immer en altijd liefdevolle sparring partner, maar vooral ook altijd mijn eigen lieve Joost.

Ik dank u allen voor uw aandacht.

Ik heb gezegd.

\section{Referenties}

Amano, T., Ushiyama, K., Fujita, G., \& Higuchi, H. (2006). Costs and benefits of flocking in foraging white-fronted geese (Anser albifrons): effects of resource depletion. Journal of Zoology, 269, 111-115.

Bakker, A.B., Van Emmerik, H., \& Euwema, M.C. (2006). Crossover of burnout and engagement in work teams. Work and Occupations, 33(4), 464-489.

Bakker, A.B., Westman, M., \& Van Emmerik, IJ.H. (2009). Introduction to the special issue: Crossover of work-related strain and engagement. Journal of Managerial Psychology, 24(3), 205.

Beyerlein, M.M., Beyerlein, S.T., \& Kennedy, F.A. (2005). Collaborative capital: Creating intangible value. London: Emerald Group.

Brenninkmeijer, V., Demerouti, E., Le Blanc, P., \& Van Emmerik, IJ.H. (2010). Regulatory focus at work: The moderating role of regulatory focus in the Job Demands-Resources Model. Career Development International, 15(7), 708-728.

Daft, R.L., \& Noe, R.A. (2001). Organizational Behavior. Mason: South-Western Publishing.

De Janasz, S.C., Dowd, K.O., \& Schneider, B.Z. (2006). Interpersonal skills in organizations. New York: McGraw-Hili.

Demerouti, E., Bakker, A.B., Nachreiner, F. \& Schaufeli, W.B. (2001). The job demandsresources model of burnout. Journal of Applied Psychology, 86(3), 499-512.

European Foundation for the Improvement of Living and Working Conditions. (2007). European Working Conditions Survey [computer file]. Colchester, Essex: UK Data Archive [distributor], May 2007. SN: 5639.

Gargiulo, M., \& Benassi, M. (2000). Trapped in your own net? Network cohesion, structural Holes, and the adaptation of social capital. Organization Science, 11(2), 183-196.

George, J.M., \& Jones, G. (2008). Understanding and managing organizational behavior. Upper Saddle River: Pearson.

Günter, H., Van Emmerik, IJ.H., Schreurs, B., Kuypers, T., Iterson, A.v., \& Notelaers, G. (2011). When conflict threatens teams: How perceived performance influences relationship conflict over time. Paper presented at the Academy of Management, San Antonio, TX. 
Harrison, D.A., Price, K.H., \& Bell, M.P. (1998). Beyond relational demography: Time and the effects of surface- and deep-level diversity on work group cohesion. Academy of Management Journal, 41(1), 96-107.

Hochschild, A.R. (1979). Emotion work, feeling rules, and social structure. The American Journal of Sociology, 85(3), 551-575.

Kanter, R.M. (1977). Some effects of proportions on group life: Skewed sex ratios and responses to token women. American Journal of Sociology, 82, 965-990.

Kats, M.M.S., Van Emmerik, IJ.H., Blenkinsopp, J., \& Khapova, S.N. (2010). Exploring the associations of culture with careers and the mediating role of HR practices: A conceptual model. Career Development International, 15(4), 401-418.

Leana, C.R., \& Van Buren, H.J. (1999). Organizational social capital and employment practices. Academy of Management Review, 24(3), 538-555.

Mathieu, J., Maynard, M.T., Rapp, T., \& Gilson, L. (2008). Team effectiveness 19972007: A review of recent advancements and a glimpse into the future. Journal of Management, 34(3), 410-476.

Mathieu, J.E., Heffner, T.S., Goodwin, G.F., Salas, E., \& Cannon Bowers, J.A. (2000). The influence of shared mental models on team process and performance. Journal of Applied Psychology, 85(2), 273-283.

Morgeson, F.P., DeRue, D.S., \& Karam, E.P. (2010). Leadership in teams: A functional approach to understanding leadership structures and processes. Journal of Management, 36(1), 5-39.

Muna, F.A., \& Mansour, N. (2005). Leadership lessons from Canada geese. Team Performance Management, 11(7/8), 316-326.

Nahapiet, J., \& Ghoshal, S. (1998). Social capital, intellectual capital, and the organizational advantage. Academy of Management Review, 23(2), 242-266.

Oh, H., Chung, M.-H., \& Labianca, G. (2004). Group social capital and group effectiveness: The role of informal socializing ties. Academy of Management Journal, $47(6), 860-875$.

Raes, A.M.L., Heijltjes, M.G., Glunk, U., \& Roe, R.A. (2011) The interface of the top management team and middle managers: A process model. Academy of Management Review, 36(1), 102-126.

Roberson, O.M. (2006). Justice in teams: The activation and role of sensemaking in the emergence of justice climates. Organizational Behavior and Human Decision Processes, 100(2), 177-192.
Salas, E., Dickinson, T.L., Converse, S.A., \& Tannenbaum, S.I. (Eds.). (1992). Toward an understanding of team performance and training. Norwood, NJ: Ablex.

Smith, M.L. (2005). Team-member exchange and individual contributions to collaborative capital in organizations. Advances in Interdisciplinary Studies of Work Teams, 11(161-181).

Tuckman, W.B. (1965). Developmental sequence in small groups. Psychological Bulletin, 63(6), 384-399.

Van Emmerik, IJ.H. (2006). Gender differences in the creation of different types of social capital: A multilevel study. Social Networks, 28(1), 24-37.

Van Emmerik, IJ.H., Euwema, M.C., Geschiere, M., \& Schouten, M. (2006). Networking your way through the organization: The relationship between participating in formal networks and career satisfaction. Women in Management Review, 21(1), 54-66.

Van Emmerik, IJ.H., Euwema, M.C., \& Bakker, A.B. (2007). Threats of workplace violence and the buffering effect of social support. Group \& Organization Management, 32, 152-175.

Van Emmerik, IJ.H., \& Euwema, M.C. (2008). The aftermath of organizational restructuring: Destruction of old and development of new social capital. Journal of Managerial Psychology, 23(7), 833-849.

Van Emmerik, IJ.H., \& Brenninkmeijer, V. (2009). Deep-level similarity and group social capital: Associations with team functioning. Small Group Research, $40(6), 650$.

Van Emmerik, IJ.H. \& Peeters, M.C.W. (2009). Crossover specificity of teamlevel work-family conflict to individual-level work-family conflict. Journal of Managerial Psychology, 24(3), 254-268.

Van Emmerik, IJ.H., Bakker, A.B., Schreurs, B., Brenninkmeijer, V., Le Blanc, P. \& Demerouti, E. (2010). Shared norms for emotion regulation strategies and associations with team in-role and extra-role performance. Paper presented at the Southern Management Association, St Petersburg, FL.

Van Emmerik, IJ.H., Gardner, W.L., Wendt, H., \& Fischer, D. (2010). Associations of culture and personality with mcclelland's motives: A cross-cultural study of managers in 24 countries. Group \& Organization Management, 35, 329-367.

Van Emmerik, IJ.H., Wendt, H., \& Euwema, M.C. (2010). Gender ratio, societal culture, and male and female leadership. Journal of Occupational and Organizational Psychology, 83, 895-914 
Van Emmerik, IJ.H., Guenter, H., Schreurs, B., De Grip, A., Van Loo, J., Agrawal, N.M., et al. (2011). Ways of measuring and monitoring employees' performance and wellbeing in different cultures Symposium at the Eastern Academy of Management - International Conference on Managing in a Global Economy XIV: Global Web of Knowledge, Bangalore, India, June 26-30.

Van Emmerik, IJ.H., Schreurs, B., De Cuyper, D., \& Jawahar, I.M. (2011). Social networks and knowledge sharing behaviors: The moderating role of HRM practices. Manuscript submitted for publication.

Van Emmerik, IJ.H., Schreurs, B.H.J., Guenter, H., \& Broeck, A.V.d. (2011). Shared work value orientations and direct and indirect associations with employees' job engagement within teams. Manuscript submitted for publication.

Van Emmerik, IJ.H., \& Van Vuuren, T. (2011). Keeping a close watch on your employees. Different ways of measuring and monitoring employees' performance and well-being. Practitioners symposium at the 15th European Congress of Work and Organizational Psychology, May, 25-28, Maastricht.

Van Emmerik, IJ.H., Euwema, M.C., \& Wendt, H. (2008). Leadership Behaviors around the World: The Relative Importance of Gender versus Cultural Background. International Journal of Cross Cultural Management, 8(3), 297-315.

Wendt, H., Euwema, M.C., \& van Emmerik, IJ.H. (2009). Leadership and team cohesiveness across cultures. Leadership Quarterly, 20(3), 358-370.

Whetten, D.A., \& Cameron, K. (2008). Developing management skills. Upper Saddle River: Pearson.

\section{Eindnoten}

The introduction, text, and pecha kucha of this inaugural lecture can be found at http://hettyvanemmerik.com/index_files/WorkingTogetherlnauguralLecture.html or http://tiny.cc/tyzfm

On this page you can find a link to the YouTube file of the introduction. Geese flying in V-formation as example of a perfect organized team. The movie clip is adapted from Winged Migration (2001). The version of Lou Reed's It's Just a Perfect Day is from the BBC cover - featuring a wide-array of artists. Artists include: David Bowie Laurie Anderson, Elton John, Emmylou Harris, Bono among many others.

\section{http://www.youtube.com/watch?v=sVxWyGMtkvc}

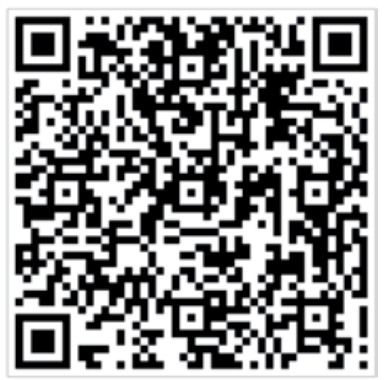


